J O URNAL OF French and Francophone Philosophy
REV UE DE LA

philosophie française et de langue française

\title{
Afterword
}

\section{Living Fanon}

\section{Lewis R. Gordon}

Journal of French and Francophone Philosophy - Revue de la philosophie française et de langue française, Vol XIX, No 1 (2011) pp 83-89

\author{
Vol XIX, No 1 (2011) \\ ISSN 1936-6280 (print) \\ ISSN 2155-1162 (online) \\ DOI $10.5195 /$ jffp. 2011.480 \\ http://www.jffp.org
}

\section{(cc) EY-No-No}

This work is licensed under a Creative Commons Attribution-Noncommercial-No Derivative Works 3.0 United States License.

\section{ULIS D-Sont}

This journal is operated by the University Library System of the University of Pittsburgh as part of its D-Scribe Digital Publishing Program, and is co-sponsored by the University of Pittsburgh Press 


\title{
Afterword
}

\section{Living Fanon}

\author{
Lewis R. Gordon
}

Temple University

Les damnés de la terre, published in 1961, offers words of life from a dying man. Orated to the author's wife Marie-Josèphe Dublé ("Josie," as she was affectionately called), typist of those narrated progenies of struggle, the text is the meeting of body to body, so to speak, as he interrogated and reached out not only to Josie but also to Jean-Paul Sartre, and through him and so many others, to us, the contemporary readers, in our continued efforts to understand, to learn, and to question. On the $6^{\text {th }}$ of December, shortly after its publication, Frantz Fanon, author of this magnificent work dubbed by the Black Panther Huey Newton as "the handbook of the revolution," was dead.

Fifty years have come to pass, and we face memorializing Fanon's death while celebrating his life through commemorating the birth of his extraordinary text. Honoring Fanon is, however, no easy task. Fanon is, after all, a thinker who struck fear and indignation in the minds of many erstwhile critics, ranging from Hannah Arendt to Michael Walzer, not only because of his thought but unfortunately also because of him or, perhaps better, his kind thinking such thoughts. He was what he described in his first book, Peau noire, masques blancs (1952), as the black, the phobogenic projection that scares reason out when he enters a room. Resistance to his thought often took the form of declaring him a prisoner of his times, locking him in his biography and more radically attempting to ensnare him in an alienated, dehumanized, and overdetermined version of his body, demonizing him as a harbinger of violence and hate, a paragon of nationalistic fervor, a lack of originality, or, worse, irrelevant, even in historical terms, to contemporary thought and politics. Such critics ignore Fanon's counsel of making sure the tool never subordinates the man.

There are, however, those who write and organize their understanding of Fanon's thought and political practice (or praxis) otherwise. From studies of his political prescience to his impact on the formation of anti-colonial, decolonial, and postcolonial theory and his challenges to the pretentions of 
the human sciences, such proponents and critics produced a body of literature that have come to be known as Fanon Studies. In addition to the usual homage-hospitals, high schools, research institutes, foundations, and awards bearing his name-perhaps most striking is the confluence of recent events in Africa and the Middle East/West Asia, much of which affirms his continued relevance, where not only Les damnés de la terre but also L'an $v$ de la révolution algérienne (1959) and the posthumous Pour la révolution africaine (1964) speak, unfortunately, to reneged promises as dimensions of the times. Along with the many forums organized in celebration and memory of this great and at times infamous revolutionary-ranging from special conferences in Cuba, Italy, Martinique, the United States, and Venezuela, among others - the rebellious acts of democratic participation and efforts to build institutions reflecting the will of the people are fitting, albeit not necessarily intended, tributes. Where, in today's world, is there a place, they seemed to be asking, for human beings to meet with dignity and respect?

A recurring emphasis in Fanon's thought is on the cultivation of the human elements of human institutions. Agents of social change get into trouble, he argued, when they attempt to make the people irrelevant to the societies they are building. This failure, faced by much of the leadership of postcolonial African and Middle Eastern states, contributed in no small part to the eruption of what is now known as "the Arab Spring," which one of our authors, Anthony Alessandrini, rightly reminds us is also "the African Spring," of 2011. Such a consideration has inspired many since the critical assessments of postcolonial leadership were offered in Les damnés de la terre in 1961, across the then Third World, including their exemplars in povertycenters and ghettoized regions of First World nations, to the now Global South, whose geopolitical terrain reach, almost perversely, into destitute regions of Eastern Europe. The spirit of Fanon in these events unavoidably organizes this tribute in this special issue of The Journal of French and Francophone Philosophy.

How, we may wonder, would Fanon have considered his reflections fifty years later? I think Anthony Alessandrini hit the proverbial nail on the head through identifying an often overlooked aspect of Fanon's relation to his own thought: Fanon wrote hoping he was wrong, which made his warnings prophetic in the sense of a warning for the sake of a genuinely contingent future. That Fanon continues to be relevant is, given that aspiration, a source of disappointment. He was a prophet beseeching his contemporaries to take responsibility for doing otherwise with hope of such protestations reaching open ears. The fifty-year disregard, of willful ignorance, malevolence, and despair, fulfills much of the negative diagnoses of the political-thinking physician. Yet for Fanon, disappointments should not occasion resignation, for failure, as he famously contended in Peau noire, masques blancs, is also an opportunity: "Si le débat ne peut pas s'ouvrir sur le plan philosophique, c'est-à-dire de l'exigence fondamentale de la réalité humaine, je 
consens à le mener sur celui de la psychanalyse, c'est-à-dire des "ratés", au sens où l'on dit qu'un moteur a des ratés." ${ }^{1}$ Failure, then, must paradoxically fail, which means to say that its success, too, is a paradox of failure. This strange observation holds within it the underside of failure in the being or series of relationships through which it could have been manifested in the first place-namely, human reality, here addressed, too, at psychoanalytical levels of anxiety and neurosis. Fanon thus, as Alessandrini also reminds us, had hoped to be wrong precisely because of that about which he was most committed to being right-that humanity is, at the most fundamental level, a yes, a healthy yes-what Alessandrini calls "optimism of the will." The pessimistic among us would say today what was urged to many agents of social change, including, ironically, those such as Mohandas Gandhi and Martin Luther King, Jr., in addition to Fanon and, I should like to add, Malcolm X and Steve Bantu Biko, namely, why couldn't they wait? Why couldn't they slow down such processes in the interest of, at least, "stability"?

Although not expanded in Alessandrini's wonderful discussion, the query hits the heart of the mythic core of the human generational condition. The conservative core, like the mythic Daedalus to Icarus, cautions against flying high (failing) on fashioned wings like Icarus aiming for the burning sun. The father Daedalus, however, forgot that Icarus and he had taken flight from captivity, which meant, in the end, that the future must be faced even with the dangers it harbors. Whether flying low or high, flight, in the end, must be taken for change to occur, and the responsibility for that, Fanon reminded us, cannot be understood through preserved captivity, which included, as Sonia Dayan-Hezbrun and Nigel Gibson remind us, the Greco-Latin pedestal of western and colonial values. This system of values is the enemy of all struggles for decolonization, the effort to make concrete the will for liberation of the colonized people; premised on the notion that the colonial situation is just, its transformation becomes an assault on justice and thus presumed intrinsically flawed. The only acceptable conditions of action become those, in effect, that do not change the status quo. Thus, the political reality becomes one of challenging the dominant conception of ethics and morals and their relation to political action. Where might truth be found in the face of such opposition? The answer, Gibson reminds us, is beyond the abstract conception of the human being outside of de facto relations of suffering and deed-namely, the concrete embodiment of truth, human beings in the flesh facing, in concert with Alessandrini's conclusion, the future to come.

Yet even if the truth succeeds in pushing aside those invested in structures of alienation, there is the question of how to proceed from there and on behalf of or for the sake of whom? Fear and trembling for the future are, after all, from the experience of reaching for paradise but having plummeted into hell. Nationalism, versus national consciousness, Jane Anna 
Gordon reminds us, has been one of the sources of such a descent. This insight echoes another from one of the great enemies of neoconservative and neoliberal political thought: Jean-Jacques Rousseau's distinction between the general will (reflective understanding of legitimacy and right at the level of political society) and the will in general (selfish aggregates of private or individual wills). "Indeed," reflects Gordon, "it was in the name of something akin to a submerged nation and general-will-in-the-making that those struggling to bring about an end to occupation charged colonial society with political illegitimacy," an observation that reveals some of the incoherence of contemporary discussions pitting democracy against the concept of sovereignty as found, say, in the work of Antonio Negri and Michael Hardt, for what is radical democracy but an appeal, ultimately, to a different form of sovereignty than the version that is an object of their critique? Without the legitimating underpinning of democratic reflection, anti-sovereignty collapses into multitudinous force. Fanon's corrective, drawn from the anti-colonial perspective of engaged struggle, Gordon correctly stresses, "emerges only out of deliberate challenges to relations of subordination and alienation," where the process of decolonization leads to the emergence of the postcolonial bourgeoisie, a pseudo-bourgeois group whose legitimacy is political without material capital, the consequence of which is, as Fanon famously argued, the absence of a telos, of an aim, which, affirming Alessandrini's and Gibson's reminder, leads to their being in the way of the nation's future. Purpose requires more than a negative reaction.

The hoped-for future, however, is one of affirmed human and humane relations, which makes the question of intersubjectivity, of the social world, of the human world, of a human being reaching for other human beings, one of a human body's relation to other human bodies, a necessary condition to be addressed. Matthieu Renault has done much service for Fanon studies in his provocative exploration of how concerns with national liberation have, in this regard, erotic undercurrents. He takes on this task through an exploration of Fanon's philosophical anthropology and, as he puts it, Fanon's "return to race as a return to the body" (original emphases). Racism offers a form of somatophobia. Tracing this understanding back to Fanon's doctoral thesis, which rejects mind-body dualism through a theory of "bodily integration," Renault argues that "... such a splitting takes its roots in what Fanon, following Freud and Jung, considers to be the crucial law of the process of (European) civilization: the law of dissociation of the white man's psyche, between intelligence and drives, morality and instincts."

I must say I take issue with Renault's formulation of Fanon as "Foucauldian" and also the notion that the body in a political relation constitutes a body politic: "What Fanon demonstrates in a kind of Foucauldian manner is that the body is always-already integrated in a political field, that it is always a body politic." This formulation is, of course, from a tendency in recent political thought to refer to a variety of a-political 
phenomena as political through use of the phrase "the politics of...," and, through Foucault, with the formulation of "biopolitics," to Pierre Bourdieu's concerns with social fields, of which "political field" is an addition, as well as Achille Mbembe's "necropolitics." The confusion is, however, on Foucault's through to Mbembe's part, in the collapse of rule and politics, where the negotiations and complex play of rule collapse into the mechanisms themselves. The ghosts here are Carl Schmitt and Thomas Hobbes, whose mechanistic atomism makes politics the enemy of order. This fear brings to the fore, however, the point, understood by Arendt and Cassirer in their understanding of Plato's relation to Socrates, where the former's prioritizing the regulation of the polis diverges from the latter's effort to live the contingencies and contradictions of life within the polis, where truth in opinion prevailed. "Politics of," then, is often unclear, especially where the structure suggests economies of distribution and resources more than their political negotiation.

Reasserting Bourdieu, "political field," as an emanation from the genealogical tree of the polis, the city, and the encroached space of oppositions, offers, however, challenges of how intersubjective relations ("social fields") could be established where flesh faces flesh. "Corps à corps," roughly translated as lived-body to lived-body, is thus another way of referring to intersubjectivity, sociality, and the conditions of culture, albeit also guided, in political terms, with considerations of power and exigency. In this sense, national liberation becomes a form of re-embodiment, which harkens back to Fanon's poignant observation, in Peau noire, masques blancs, of what happened to his presumed imago under a white boy's observation of his being un nègre: he exploded ("J'explosai"). Reductionistic embodiment, which included the sexualization of colonized bodies, required a liberation of embodiment without Manichean separations of a rational mind from a sexualized body-the latter made existentially serious as the black. As Renault correctly urges: "What is needed is not a desexualization but much more a decolonization of sexuality." The connection between sex, body-tobody, and life leads to his insightful conclusion of political vitalism or a political philosophy of life, wherein violence and life are connected in their etymological roots, no doubt reminiscent of Nietzsche's important reminder in The Birth of Tragedy that a life without suffering would be best achieved through not ever having lived. ${ }^{2}$

Symbolism of life and death is pushed further in Anjali Prabhu's poignant exploration of Roland Barthes's trope of the death of the author through this commemorative situation of de facto death and celebrated legacy. The author, however, is complicated here by the rhetorical strategies of evocation and meta-displacement, where the Fanons of Peau noire, masques blancs are brought into reflection and engagement with the one of Le damnés de la terre. That "the author," this particular author (Fanon), is dead while he lives calls for the question of how he is imagined or, in Prabhu's words, 
dreamed. The dream of dreaming, of the colonized and native's dream of freedom from, in Fanon's words, "entre neuf heures du soir et six heures $d u$ matin," leads in the postcolonial situation of mystifying leadership. ${ }^{3}$ Prabhu's exploration of Fanon's critical movements from " $\mathrm{I}$ " to "we" brings to the fore the problem of dangerous splitting, discussed so well, as we have seen, by Renault, in the neocolonial re-evocation of schisms the overcoming of which was previously attempted in the decolonial struggle.

So we come to a close with Sonia Dayan-Hezbrun, who lived through so many of the historical circumstances of Fanon's efforts in the French context, of the Algerian war and other struggles of liberation, in addition to their legacies, which Fanon was not able to witness. These include not only the tragic circumstances wrought by neocolonialism and the failures of postcolonial elites but also the emergence of the academic efforts to understand those events and their impact on political thought and practice. Contextualizing these events through the work of Edward Said, whose influence on academic postcolonial theory and the formation of the academic public intellectual, brought to the fore many of the tensions posed by the impact of poststructuralism, especially as articulated by Michel Foucault, on the last quarter of the twentieth century and the dawn of the twenty-first, and the decolonizing challenges posed by Fanon. A period marked by the rise of neoconservative and neoliberal global hegemony in the face of postmodern obsessions with anonymous and micro models of power, the devastating effect is a form of political nihilism ironically premised upon political excess; what can one do when everything is presumed powerful and, by extension, political? Dayan-Hezbrun expresses a retrospective lamentation: "Cependant la trajectoire de Foucault a suivi une voie diamétralement opposée à celle de Fanon. En dépit de ses premiers centres d'intérêt (l'asile, la prison), Foucault a très vite été convaincu qu'il n'était guère possible de résister." Even more problematic has been the influence of poststructural postcolonialism in disciplinary efforts premised upon liberation concerns of oppressed peoples. Particularly significant in this context, where Black Studies and Africana Studies, in addition to varieties of race and ethnic studies, were influenced by the emergence of forms of cultural studies heavily influenced by poststructuralism, was in some instances the eclipsing of liberatory discourses by epistemic and semiological ones and, in a strange development, forms of commodification of intellectual practices, where even the critique of Eurocentrism functioned more like an academic commodity. ${ }^{4}$ The result, then, was a regrettable, affirmed marginalization from the source: "Au-delà de cet eurocentrisme, Foucault ne conçoit pas la possibilité pour les groupes opprimés de se libérer." Said understood the importance of thinking through the condition of les damnés without the pitfalls of presumed innocence, which brought him to Fanon, Dayan-Hezbrun correctly argues, as a critical reflection of his own responsibility. To be part of but not fully belonging to the society whose self-image is under investigation-Fanon as a not-absolutely-French 
Frenchman, Said as a not-absolutely-American Palestinian-Americanraised the value of the existential-political critique eclipsed in the poststructural moment, a question faced by the hybrid postcolonial bourgeoisie in whose hands is the fate of national consciousness: Fanon's work, insists Dayan-Hezbrun, “...n'est pas seulement celle d'une théorie de la résistance et de la décolonisation. C'est une véritable contre-narration de la libération, comme le confirment les pages qu'il consacre à la bourgeoisie nationale et aux risques qu'elle fait courir à la révolution en cours." Self-critique is meaningless without the ability to act upon it, which radicalizes the problem of political responsibility.

But to what, ultimately, does all this responsibility point? To some extent, Fanon's passion, his sense of urgency, was a profound faith in humanity in the face of no less than the end of the world. For he knew that the Europe to which he referred in the famous conclusion to Les damnés de la terre was ultimately metaphorical. It was a dream whose greatest nightmare was the absence of its own necessity. Its continued production is premised upon the confusion of it with the world itself. But beyond all that is the human held captive beneath, whose future requires "pensée neuve," provided, of course, that we continue to have the good fortune of sufficient time.

${ }^{1}$ Frantz Fanon, Peau noire, masques blancs (Paris: Éditions du Seuil, 1952), 18.

2 On this matter of life philosophy, especially in terms of its impact on Négritude and the philosophical context of Fanon's thought, cf. also Donna Jones, The Racial Discourses of Life Philosophy: Négritude, Vitalism, and Modernity (New York: Columbia University Press, 2010). For the perspective that offers a critique of a political philosophy of war, and by extension also supporting a philosophy of life but from the perspective of decoloniality, see Nelson MaldonadoTorres, Against War: Views from the Underside of Modernity (Durham, NC: Duke University Press, 2008).

${ }^{3}$ Frantz Fanon, Les damnés de la terre, préface de Jean-Paul Sartre (Paris: Éditions Gallimard, 1991), pp. 82-83. Originally published in Paris in 1961 by François Maspero.

${ }^{4}$ For comprehensive discussions and portraits of some of these issues, see A Companion to AfricanAmerican Studies, eds. Lewis R. Gordon and Jane Anna Gordon (Malden, MA: Blackwell Publishers, 2006) and Not Only the Master's Tools: African-American Studies in Theory and Practice (Boulder, CO: Paradigm Publishers, 2006). 